\title{
Crowding-Out and Crowding-In Effects of Public Borrowing on Private Domestic Investment in Nigeria
}

\author{
Mathias A. Chuba \\ Department of Economics, Achievers University Owo, \\ Km 1, Idasen-Ute Road, P. M. B. 1030, Ondo State, Nigeria
}

\begin{abstract}
Monetarists believe that public domestic borrowing crowds-out private domestic investment (PDI) and Keynesians believe that it does not crowd-out PDI. Most previous studies focused on the crowding-out effect of public spending on PDI but the point of contention between monetarists and Keynesians is the effect of increased public domestic borrowing on PDI. The results of the previous investigation that public domestic borrowing crowded-in and public external borrowing crowdedout private domestic investment in Nigeria are questionable. In view of the above stated problems, this paper determined the effect of public borrowing on PDI in Nigeria from 1986 to 2019 using a vector error correction model. The results of the investigation showed that public domestic borrowing drove-up interest rate. PDI was found to be negatively related to interest rate. Domestic credit provided by banks is positively related to interest rate. Public domestic borrowing crowded-out and public external borrowing crowded-in PDI. This paper suggests that instead of borrowing money from internal sources, the government should borrow money from external sources to finance the federal budget deficits in order to increase PDI in Nigeria.
\end{abstract}

Keywords: Private Domestic Investment, Public Borrowing, Vector Error Correction Model, Nigeria

JEL Classification: E52, E62, H62

\section{INTRODUCTION}

$\mathrm{W}$ hen there is a federal budget deficit, government borrows money from the credit market to finance the deficit. Government borrows money to finance the deficit from both domestic and external sources. In literature, there are two different views regarding crowding-out effect of public domestic borrowing on private domestic investment. They are monetarist and Keynesian views. In monetarist view, an increase in public domestic borrowing drives up interest rate and crowds-out private domestic investment. In Keynesian view, an increase in public domestic borrowing does not drive up interest rate and crowds-out private domestic investment (Amacher and Ulbrich, 1986). The public external borrowing crowds-in private domestic investment based on the dual gap theory. The dual gap theory states that the governments in developing countries borrow money from external sources in order to fill the domestic savings and the foreign exchange gaps. The domestic savings gap exists when the domestic savings capacity falls below that necessary to permit the level of investment required to achieve a particular rate of growth of gross domestic product (GDP) while available imports are adequate. In this situation, foreign financial resources cover this gap or make up the deficits and permit achievement of the GDP growth rate. The foreign exchange gap exists if with adequate domestic savings, the flow of import is not sufficient because there is inadequate foreign exchange to finance it. Here again, foreign capital breaks the import bottlenecks and permits the targeted growth rate to be realized.

Most previous studies except that by Nwaeze (2017) focused on the crowding-out effect of public spending on private domestic investment but the point of contention between monetarists and Keynesians is the effect of increased public domestic borrowing on private domestic investment. Nwaeze investigated the crowding-out effect of public borrowing on private domestic investment in Nigeria but that study does not capture the supply side of the credit market. A good analysis of the credit market involves the discussion of both the demand and supply sides of the market. The finding by Nwaeze that public domestic borrowing has a positive relationship with private domestic investment implies that public domestic borrowing crowds-in private domestic investment and this finding is in doubt because it is not in tandem with economic theory. The finding by Nwaeze that public external borrowing has a negative relationship with private domestic investment indicates that public external borrowing crowds-out private domestic investment and this finding is questionable because it does not conform to economic theory. This study is necessary in order to confirm Nwaeze's research findings and to ascertain whether the monetarist view or the Keynesian view about the crowdingout effect of public domestic borrowing on private domestic investment is applicable to Nigeria.

In view of the above statement of the problem, this study is guided by the following research questions. (1) What are the effects of public borrowing on interest rate in Nigeria? (2) What is the effect of interest rate on private domestic investment in Nigeria? (3) What is the effect of interest rate on domestic credit provided by banks in Nigeria? (4) What is the effect of public domestic borrowing on private domestic investment in Nigeria? (5) What is the effect of public external borrowing on private domestic investment in Nigeria?

The main objective of this paper is to determine the crowdingout and crowding-in effects of public borrowing on private domestic investment in Nigeria from 1986 to 2019. The followings are the specific objectives of this study. (1) To 
determine the effects of public borrowing on interest rate. (2) To determine the effect of interest rate on private domestic investment (the demand for loanable funds). (3) To determine the effect of interest rate on domestic credit provided by banks (the supply of loanable funds). (4) To determine the effect of public domestic borrowing on private domestic investment. (5) To determine the effect of public external borrowing on private domestic investment.

This study is significant because it demonstrates that public domestic borrowing has a crowding-out effect on private domestic investment and public external borrowing has a crowding-in effect on private domestic investment and it suggests that government should borrow money only from external sources to finance her budget deficit. This study shows that the financing of the budget deficit from external sources, by increasing the domestic credit provided by banks, leads to the reduction of interest rate. This paper demonstrates that interest rate falls and private domestic investment increases as government borrows money from external sources to finance her budget deficit. This paper consists of five sections. The next section is literature review. Section 3 presents the methodology. The results are discussed in section 4 and conclusions based on research findings are drawn in section 5 .

\section{LITERATURE REVIEW}

In monetarist view, all loan-able funds are already spoken for and so the supply curve for loan-able funds is vertical. Government borrowing can come only at the expense of private borrowers. If government borrowing increases, the demand curve for loan-able funds increases and interest rates rise because the slope of the supply curve for loan-able funds is vertical. As interest rates rise, private investment falls. The rise in government spending due to an increase in government borrowing is offset by an equal fall in private investment, as interest rates rise. This is pure crowding-out (Amacher and Ulbrich, 1986).

In Keynesian view, there are ample loan-able funds available at the current interest rates. Banks have excess reserves but are reluctant to lend to risky private borrowers. However, they will lend freely to the government because they are certain of repayment. Government borrowing has no effect on interest rates because there are funds available at the existing interest rate. If government borrowing increases, the demand curve for loan-able funds increases but interest rates do not rise because the slope of the supply curve for loan-able funds is horizontal. Since interest rates do not rise, private investment is unaffected. No crowding-out occurs. Even if interest rates rise, private investment may not be affected because Keynesians believe that investment is influenced much more by final demand, profit expectations, existing stock of capital, corporate taxes and change in technology than interest rates (Amacher and Ulbrich, 1986).

According to Ricardo (1820), government spending must be financed, now or in the future, by taxes. The more taxes imposed by the government in the future, the less disposable income for the private sector, negatively affecting private investment. On the other hand, public investment can, again directly or indirectly, create favorable conditions for private investment, for instance, by providing infrastructure such as roads, highways, sewage systems, and harbors. Better facilities may increase the productivity of private investment and reduce the cost of production of the private sector, a positive impact on the profitability of private investment. This would result in a "crowding-in" effect on private investment. Furthermore, government spending itself may directly crowd in private investment, by contracting directly with private. State enterprises can also subcontract to private firms, directly increasing private investment (Xu and Yan, 2014). Thus, government spending will not have an impact on private investment due to the Ricardian equivalence.

In classical view, the supply of credit (loan-able funds) results from people's decision to save, while the demand for credit results from the desire by businesses to borrow money for the purpose of investment. The supply schedule has a positive slope to indicate that the supply of loan-able funds (saving) is directly related to the interest rate. This is based on the argument that people forgo spending (save) only if there is an incentive to do so. The interest rate is the incentive for saving. That is, by saving now, individuals can earn interest and accumulate larger sums of money to spend in the future. When interest rate rises, the incentive to save increases and so the quantity of saving increases. When interest rate declines, the incentive to save declines and so the quantity of saving declines.

The demand schedule has a familiar negative slope which indicates that the demand for loan-able funds (investment) will increase when interest rate declines and decrease when interest rate rises. This is because interest rate is the price businesses pay to obtain credit. When the price is lower, businesses will demand more credit for investment; when the price is higher, they will demand less credit for investment.

According to classical economists, the credit market would establish an equilibrium interest rate which would equate the amount of saving and investment spending. The equilibrium interest rate is determined by the intersection of the saving and investment schedules. At interest rates above equilibrium, the supply exceeds the demand for credit, and the surplus of saving relative to investment spending forces the interest rate downward to equilibrium interest rate. At interest rates below equilibrium, demand exceeds the supply of credit. This shortage causes the interest rate to be bid up to equilibrium interest rate.

Suppose people suddenly became more thrifty; that is, the amount of saving increased at each interest rate. In this case, the saving schedule would shift to the right. The new equilibrium interest rate would be below the initial equilibrium interest rate. The increase in saving would, by lowering the price of credit, lead to an increase in the amount of investment spending (Amacher and Ulbrich, 1986). 
The dual gap theory states that the governments in developing countries borrow money from external sources in order to fill the domestic savings and the foreign exchange gaps. The domestic savings gap exists when the domestic savings capacity falls below that necessary to permit the level of investment required to achieve a particular rate of growth of gross domestic product (GDP) while available imports are adequate. In this situation, foreign financial resources cover this gap or make up the deficits and permit achievement of the GDP growth rate. The foreign exchange gap exists if with adequate domestic savings, the flow of import is not sufficient because there is inadequate foreign exchange to finance it. Here again, foreign capital breaks the import bottlenecks and permits the targeted growth rate to be realized.

There are many empirical studies on crowding-out in both developed and developing countries.

Mittnik and Neumann (2001) evaluated the dynamic effects of public investment on private investment in 6 industrialized countries including Canada, France, UK, Japan, Netherlands, and Germany from 1955 to 1994 using vector autoregressive (VAR) model. They found that public investment crowds-in private investment in 3 out of 6 of these countries.

Voss (2002) investigated crowding-out effect of public investment on private investment in the United States and Canada from 1947:Q1 to 1988:Q1 applying VAR model in data analysis. The results of the investigation revealed that public investment crowds-out private investment.

Afonso and Sousa (2011) determined the macroeconomic effects of fiscal policy in Portugal from 1979:Q1 to 2007:Q4 using a Bayesian structural vector autoregressive (SVAR) analysis. They found that government spending crowds-out private investment.

$\mathrm{Xu}$ and Yan (2014) investigated whether government investment crowds-out private investment in China from 1980 to 2011 using SVAR analysis. They divided government capital expenditures into two types: (1) investment that serves to provide public goods and infrastructure, and (2) investment in private industry and commerce. They found that government investment in public goods crowds-in private investment significantly while government investment in private goods, industry and commerce, mainly through stateowned enterprises, crowds-out private investment significantly.

Karagöl (2004) investigated the crowding-out effects of the components of government expenditure on private investment in Turkey from 1968 to 2000 using co-integration analysis of a multivariate system of equations. The results of the investigation showed that government investment and consumption crowd-out private investment.

Kuştepeli (2005) investigated the crowding-out or crowdingin effect of fiscal spending on private investment in Turkey from 1963 to 2003 and 1967-2003 utilizing Johansen cointegration test. The results of the investigation showed that government spending crowds-in private investment and government deficits crowd-out private investment.

Furceri and Sousa (2011) evaluated the crowding-out or crowding-in effect of government spending on private sector in 145 developed and developing countries from 1960 to 2007 using a panel data. They found that government spending crowds-out both private investment and private consumption. They tested whether the impact of government spending on private sector spending varies among regions and whether it depends on the phase of the business cycle. They found that the impact of government spending on private sector spending varies significantly among countries, but it does not depend on the phase of the business cycle.

Gjini and Kukeli (2012) evaluated the crowding-out effect of public investment on private investment in 6 developing and 5 developed market economies in Eastern Europe from 1991 to 2009. They used the Weighted Least Squares (WLS) econometric model due to the fact that countries differ in many respects and one would find it as plausible to think that space intercept is specific for each of the countries included in the sample. Their preliminary results showed that public investment did not crowd-out private investment in the market economies in Eastern European continent. Using pooled cross sectional analysis, the data confirm the structural break of private investment behavior between developing and developed countries.

Mahmoudzadeh et al. (2013) determined the crowding-out effect of fiscal spending on private investment in 23 developed and 15 developing countries from 2000 to 2009 using a panel data. They found that the budget deficits crowdout private investment in developed countries and crowd-in private investment in developing countries but the effects were statistically insignificant in both developed and developing countries.

Atukeren (2005) examined the interactions between public and private investment in 25 developing countries from 1970 to 2000 applying co-integration analysis and Grangercausality tests. It was found that public investment crowds-out private investment in eleven countries and public investment crowds-in private investment in eight countries. The public investment did not crowd-out or crowd-in private investment in six countries.

Mitra (2006) investigated whether government investment has crowded-out private investment in India from 1969 to 2005 utilizing SVAR model. The results of the investigation indicated that government investment crowded-out private investment.

Bahal et al. (2015) investigated whether public investment crowds-out or crowds-in private investment in India from 1950 to 2012 using structural vector error correction models (SVECMs). Acknowledging the major structural changes that the Indian economy has undergone in the past three decades, they studied whether public investment in recent years has become more or less complementary to private investment in 
comparison to the period before 1980. They found that public investment crowds-out private investment from 1950 to 2012 and public investment crowds-in private investment when they restricted the sample post 1980 or conducted a quarterly analysis since 1996Q2. According to them this change can most likely be attributed to the policy reforms which started during early 1980s and gained momentum after the 1991 crises.

Kollamparambil and Nicolaou (2011) analyzed the nature and association of public and private investment in South Africa for three different periods, 1946 to 2005, 1960:Q1 to 2006:Q1, and 1965 to 2005 using VAR model. They found that public investment does not crowd-in or crowd-out private investment, but it increased private investment through accelerator principle.

Omojolaibi et al. (2016) evaluated the crowding-out effect of fiscal policy on private investment in five selected West African countries from 1993 to 2014 employing fixed effect model for panel data ordinary least square approach. They found that government capital expenditure and tax revenue have a significant crowding in effect on private investment and non-tax revenue has a significant crowding-out effect on private investment. Recurrent expenditure and external debt were found to have insignificant crowding-out effect on private investment. The accelerator effect of output growth was also found to be insignificant across the countries investigated.

Ifeakachukwu et al. (2013) determined the relationship between components of public spending and private investment in Nigeria from 1981 to 2010 using error correction model. Private investment was measured by credit to the private sector and foreign direct investment. They found that components of public spending have different relationships with private investment both in the long run and in the short run. Specifically, public recurrent and final consumption expenditures have a positive relationship with private investment and public capital expenditure has a negative relationship with private investment. This implies that public recurrent and final consumption expenditures crowd-in private investment and; public capital expenditure crowds-out private investment in Nigeria.

Nwaeze (2017) investigated the crowding out effect of public borrowing on private investment in Nigeria from 1970 to 2016 using VAR model. Domestic credit to the private sector was used as a proxy for private domestic investment. The study found a positive relationship between private domestic investment and public domestic borrowing, implying that public domestic borrowing crowds-in private domestic investment in Nigeria. The study also found a negative relationship between private domestic investment and public external borrowing, implying that public external borrowing crowds-out private domestic investment in Nigeria.

Omitogun (2018) investigated the crowding-out effect of government expenditure on private investment in Nigeria from 1981-2015 using descriptive statistics, correlation matrix, a unit root test and Auto Regressive Distributed Lag (ARDL) method. The study investigated the effect of disaggregated government expenditure on private investment in Nigeria. It was observed in general that the effect of government expenditure on private investment depends on the components of the expenditure. Some were found to crowdout private investment while some crowd-in private investment. This implies that not all government expenditure is channeled in such a way that it attracts private investment in the economy. It is therefore recommended that the policymakers should take into consideration the existence of private investors in expenditure plans.

Most previous studies except that by Nwaeze (2017) focused on the crowding-out effect of public spending on private domestic investment but the point of contention between monetarists and Keynesians is the effect of increased public domestic borrowing on private domestic investment. Nwaeze investigated the crowding-out effect of public borrowing on private domestic investment in Nigeria but that study does not capture the supply side of the credit market. A good analysis of the credit market involves the discussion of both the demand and supply sides of the market. The finding by Nwaeze that public domestic borrowing has a positive relationship with private domestic investment implies that public domestic borrowing crowds-in private domestic investment and this finding is in doubt because it is not in tandem with economic theory. The finding by Nwaeze that public external borrowing has a negative relationship with private domestic investment indicates that public external borrowing crowds-out private domestic investment and this finding is questionable because it does not conform to economic theory. This study is necessary in order to confirm Nwaeze's research findings and to ascertain whether the monetarist view or the Keynesian view about the crowdingout effect of public domestic borrowing on private domestic investment is applicable to Nigeria.

\section{METHODOLOGY}

\subsection{Theoretical Framework of the Study}

The theoretical framework of the study is the monetarist's view of the effect of increased government borrowing on private domestic investment. In monetarist view, all loan-able funds are already spoken for and so the supply curve for loanable funds is vertical. Government borrowing can come only at the expense of private borrowers. If government borrowing increases, the demand curve for loan-able funds increases and interest rate rises because the slope of the supply curve for loan-able funds is vertical. As interest rate rises, private investment falls. The rise in government spending due to an increase in government borrowing is offset by an equal fall in private investment, as interest rate rises. This is pure crowding-out (Amacher and Ulbrich, 1986).

\subsection{Model Specification}

Based on the theoretical framework of the study, private domestic investment, public borrowing (which is split into 
public domestic borrowing and public external borrowing), domestic credit provided by banks, and lending interest rate are included in the model. The functional form of the model for this study is stated in equation (1) below.

$$
\mathrm{PDI}_{\mathrm{t}}=\mathrm{f}\left(\mathrm{PDB}_{\mathrm{t}}, \mathrm{PEB}_{\mathrm{t}}, \mathrm{DCB}_{\mathrm{t}}, \mathrm{INR}_{\mathrm{t}}\right.
$$

Where PDI is private domestic investment, PDB is public domestic borrowing, PEB is public external borrowing, DCB is domestic credit provided by banks, INR is lending interest rate, subscript $t$ is current time and $\mathrm{f}$ is functional notation. The linear form of equation (1) is:

$$
\begin{aligned}
& \quad \operatorname{LnPDI}_{\mathrm{t}}=\mathrm{b}_{0}+\mathrm{b}_{1} \operatorname{LnPDB}_{\mathrm{t}}+\mathrm{b}_{2} \operatorname{LnPEB}_{\mathrm{t}}+ \\
& \mathrm{b}_{3} \operatorname{LnDCB}_{\mathrm{t}}+\mathrm{b}_{4} \mathrm{INR}_{\mathrm{t}}+\mathrm{e}_{\mathrm{t}}
\end{aligned}
$$

Where $b_{0}$ is intercept, $b_{1}$ to $b_{4}$ are the regression coefficients and $e_{t}$ is the error term at time $t$. All the variables except interest rate are transformed to logarithms in order to be of the same standard.

This paper follows Palić et al. (2017) to utilize the Johansen approach to cointegration and vector error correction model to determine the relationships among a set of economic variables. The vector error correction model is used for this study because of three reasons. First, the time series are not stationary in their levels but are in their first differences. Second, the variables are co-integrated. Third, the variables of interest are simultaneously related, hence the need to treat each variable symmetrically and allow feedback among them.

The VECM is superior to a single equation approach for capturing the long run dynamics of variables (Enders, 1995 and Feasel et al. 2001). This technique enables us to verify the stationarity as well as the order of integration of the variables that are used in the model. The VECM also saves one from the agony of endogeneity problem and the inherent spurious inferences associated with OLS estimates.

The Johansen approach to co-integration is described in brief in this section. If the set of economic variables is observed, the long-run equilibrium can be written as:

$$
\Pi \mathrm{Z}_{\mathrm{t}}+\mathrm{e}_{\mathrm{t}}=0,
$$

Where $\Pi$ is matrix of parameters, $Z_{t}$ is vector consisted of $n$ economic variables, $e_{t}$ is vector of innovations or vector of stationary random variables (Bahovec, Erjavec, 2009). The equilibrium is reached if $\Pi Z_{t}=0$. In that case, the deviation from the long-run equilibrium is given by:

$$
\mathrm{e}_{\mathrm{t}}=-\Pi \mathrm{Z}_{\mathrm{t}}
$$

If the long-run equilibrium is reached, the deviation $e_{t}$ is described to be a stationary process. It has to be emphasized that there are some differences between long-run equilibrium definition of economic theorists and of econometricians. Economic theorists use this term in the sense of equality between actual and desired state of economic variables. In econometric sense, the term refers to the long-run relationship between non-stationary variables. Cointegration does not require the long-run equilibrium to be the result of a market mechanism or behavior of individuals (see, for example, Palić et al., 2016)[ Palić et al., 2017].

The vector error correction model is given by:

$$
\begin{aligned}
& \Delta \mathrm{Z}_{\mathrm{t}}=\Gamma_{1} \Delta \mathrm{Z}_{\mathrm{t}-1}+\Gamma_{2} \Delta \mathrm{Z}_{\mathrm{t}-2}+\cdots+ \\
& \Gamma_{\mathrm{k}} \Delta \mathrm{Z}_{\mathrm{t}-\mathrm{k}+1}+\Pi \mathrm{Z}_{\mathrm{t}-\mathrm{k}}+\mathrm{e}_{\mathrm{t}}
\end{aligned}
$$

Where $\Gamma_{\mathrm{i}}=\mathrm{A}_{\mathrm{i}}+\mathrm{A}_{\mathrm{i}-1}+\cdots+\mathrm{A}_{1}-\mathrm{I}, \Gamma_{\mathrm{k}}=\Pi=$ $A_{k}+A_{k-1}+\cdots+A_{1}-I, A_{1}, A_{2}, \ldots, A_{k}$ are square matrices of the order $n, k$ is the lag length, and $\mathrm{i}=1,2, \ldots, \mathrm{k}$ 1 . In the equation (5) the term $\Pi Z_{t-k}$ is observed as the long-run part of the model, whereas the short-run is presented by

$$
\sum_{\mathrm{i}=1}^{\mathrm{k}-1} \Gamma_{\mathrm{i}} \Delta \mathrm{Z}_{\mathrm{t}-\mathrm{i}}
$$

(Bahovec, Erjavec, 2009). In order to determine the number of cointegration relations, the rank of matrix $\Pi$ must be observed. There are three possible situations. If matrix $\Pi$ is a zero-matrix, the co-integration is not present. If matrix $\Pi$ is of full rank or the rank is equal to the number of variables in the model (rank is equal to n), it is said that the process is stationary. If the rank of matrix $\Pi$ is not full or the rank is lower than the number of variables in the model (rank is lower than $\mathrm{n}$ ), it is said that the process is non-stationary. The matrix $\Pi$ can be written as:

$$
\Pi=\alpha \beta,
$$

Where $\alpha$ is the matrix of error correction speed (speed of variables needed to return in equilibrium), $\beta$ is the cointegration matrix (contains the parameters of long-run equations). Both matrices, $\alpha$ and $\beta$, are of rank $n$. $r$. Consequently, there are $r$ cointegration relations between variables. In order to determine the number of cointegration relations, the maximum eigenvalue test and trace test are conducted. For the detailed explanation of maximum eigenvalue test and trace test see Bahovec, Erjavec (2009) and Enders (2015)[ [ Palić et al., 2017].

\subsection{Estimation Method}

The VECM is estimated using e-view 10. The time series properties of the data are analyzed using Augmented DickeyFuller (ADF) unit root test of Dickey and Fuller (1979). Test of co-integration is carried out using the Johansen (1988) maximum likelihood procedure. The lag length is determined by the likelihood ratio (LR), final prediction error (FPE), Akaike information criteria (AIC), Schwarz information criteria (SC), and Hannan-Quinn information criteria (HQ). The VEC Residual Serial Correlation LM Tests are used to 
verify the assumption of no serial correlation or no autocorrelation. The VEC Residual Normality Tests are used to verify the assumption that the residuals are normally distributed. The Inverse Roots of AR Characteristic Polynomial is used to verify whether the VEC model is stable.

\subsection{Data}

The empirical analysis is conducted using annual data. The time span covered is 1986 to 2019. The choice of 1986 as the base year is due to the fact that the policy of deregulation of Nigerian economy started that year. The choice of 2019 as the terminal year is premised on the fact that the time series data of the variables required for the study are available only up to that year. This study is confined within the period of deregulation in other to take into cognizance the classical view of a capitalist economic system. The data of domestic credit to the private sector by banks, federal government's domestic debt outstanding, Nigeria's public external debt outstanding, domestic credit provided by banks, and weighted average prime lending rates of deposit money banks that are used for this study are obtained from Central Bank of Nigeria Statistical Bulletin, Volume 30, December, 2019. Domestic credit to the private sector by banks (demand for loan-able funds) is a proxy of private domestic investment because the demand for loan-able funds is for the purpose of investment. The federal government's domestic debt outstanding, Nigeria's public external debt outstanding, and weighted average prime lending rates of deposit money banks are proxies of public domestic borrowing, public external borrowing, and interest rate respectively. Domestic credit provided by banks (supply of loan-able funds) results from people's decision to save.

\section{RESULTS}

\subsection{Pre-Estimation Tests}

The unit root test is conducted using Augmented DickeyFuller (ADF) test (Table 1). All the variables are nonstationary at levels because ADF test statistic is less than test critical values in absolute terms at 1 percent, 5 percent and 10 percent levels of significance and p-value of each variable is greater than 5 percent. All the variables are stationary at first differences because ADF test statistic is greater than test critical values in absolute terms at 1 percent, 5 percent and 10 percent levels of significance and p-value of each variable is less than 5 percent. The ADF test indicates that the variables are of same order of integration at 1 percent, 5 percent and 10 percent level of significance. The five variables are cointegrated because they are of the same order of integration.

Table 1: Augmented Dickey-Fuller Test

\begin{tabular}{|c|c|c|c|c|c|}
\hline \multirow[b]{2}{*}{ Variables } & \multicolumn{2}{|c|}{ Levels } & \multicolumn{2}{|c|}{ First Differences } & \multirow{2}{*}{$\begin{array}{c}\text { Order of } \\
\text { Integratio } \\
n\end{array}$} \\
\hline & $\begin{array}{c}\text { ADF } \\
\text { test } \\
\text { statistic }\end{array}$ & Prob* & $\begin{array}{c}\text { ADF test } \\
\text { statistic }\end{array}$ & Prob* & \\
\hline LNPDI & -1.3804 & 0.5798 & -5.8631 & 0.0000 & $\mathrm{I}(1)$ \\
\hline LNPDB & -2.0089 & 0.2817 & -7.8245 & 0.0000 & $\mathrm{I}(1)$ \\
\hline LNPEB & -1.5587 & 0.4916 & -4.3921 & 0.0015 & $\mathrm{I}(1)$ \\
\hline LNDCB & -0.7018 & 0.8327 & -6.3756 & 0.0000 & $\mathrm{I}(1)$ \\
\hline INR & -2.4991 & 0.4111 & -5.2287 & 0.0002 & $\mathrm{I}(1)$ \\
\hline
\end{tabular}

$\begin{array}{lllll}\text { Test critical values: } 1 \% \text { level } & -3.6999 & 5 \% \text { level } & -2.9763\end{array}$

$10 \%$ level -2.6274

*Mackinnon (1996) one sided p-values

Source: Author's Computation Using E-view 10.

The co-integration test was conducted using Johansen test for co-integrating vectors (Table 2). The Trace statistic is greater than 5 percent Critical Value and p-value is less than 5 percent for all the hypothesized numbers of co-integrating equations. The Trace test denotes rejection of all the hypothesized numbers of co-integrating equations at 5 percent level. The Trace test indicates 5 co-integrating equations at the 5 percent level. The Max-Eigen statistic is greater than 5 percent Critical Value and p-value is less than 5 percent for none, at most 2 and at most 4 hypothesized numbers of co-integrating equations. The Max-Eigen statistic is less than 5 percent Critical Value and p-value is greater than 5 percent for at most 1 and at most 3 hypothesized numbers of co-integrating equations. The Maximum Eigenvalue test denotes rejection of none, at most 2 and at most 4 hypothesized numbers of cointegrating equations at the 5 percent level. The Maximum Eigenvalue test indicates 1 co-integrating equation at the 5 percent level. Both the Trace and Maximum Eigenvalue tests indicate that the variables are co-integrated or there is longrun equilibrium relationship among the variables. Since the variables are co-integrated and are stationary in their first differences, the VECM is applied in data analysis.

Table 2: Johansen Test for Co- integrating Vectors

\begin{tabular}{|c|c|c|c|c|c|c|c|}
\hline \multicolumn{2}{|c|}{ Hypothesized No. of CE(s) } & \multicolumn{3}{|c|}{ Trace } & \multicolumn{3}{c|}{ Maximum Eigenvalue } \\
\hline Trace & $\begin{array}{c}\text { Maximum } \\
\text { Eigenvalue }\end{array}$ & $\begin{array}{c}\text { Trace } \\
\text { Statistic }\end{array}$ & $\begin{array}{c}0.05 \text { Critical } \\
\text { Value }\end{array}$ & Prob** & $\begin{array}{c}\text { Max-Eigen } \\
\text { Statistic }\end{array}$ & $\begin{array}{c}0.05 \text { Critical } \\
\text { Value }\end{array}$ & Prob* \\
\hline None* & None* & 107.6447 & 69.8189 & 0.0000 & 45.9474 & 33.8769 & 0.0012 \\
\hline At most $1^{*}$ & At most 1 & 61.6973 & 47.8561 & 0.0015 & 24.0138 & 27.5843 & 0.1342 \\
\hline At most $2^{*}$ & At most 2* & 37.6835 & 29.7971 & 0.0050 & 22.0971 & 21.1316 & 0.0365 \\
\hline At most 3* & At most 3 & 15.5864 & 15.4947 & 0.0485 & 10.9856 & 14.2646 & 0.1549 \\
\hline At most 4* & At most 4* & 4.6008 & 3.8415 & 0.0320 & 4.6008 & 3.8415 & 0.0320 \\
\hline
\end{tabular}

*denotes rejection of the hypothesis at the 0.05 level

** Mackinnon- Haug- Michelis (1999) p-values

Source: Author's Computation Using E-view 10. 
The lag length selection was done using the VAR Lag Order Selection Criteria (Table 3). The Final prediction error (FPE), Akaike information criterion (AIC) and Hannan-Quinn information criteria (HQ) indicate maximum lag length 3 and Schwarz information criterion indicates maximum lag length 1 at 5 percent level. The sequential modified LR test statistic (LR) does not indicate any lag length. Since the value of FPE (0.0007) at lag 3 is the smallest out of the values indicated by these four criteria, the VECM is estimated at a maximum lag length 3 based on Final prediction error (FPE).

Table 3: VAR Lag Order Selection Criteria

\begin{tabular}{|c|c|c|c|c|c|}
\hline Lag & LR & FPE & AIC & SC & HQ \\
\hline 1 & NA & 0.0010 & 7.2839 & $8.4516^{*}$ & 7.6574 \\
\hline 2 & 34.5246 & 0.0011 & 7.2243 & 9.5597 & 7.9714 \\
\hline 3 & 36.8330 & $0.0007^{*}$ & $6.4355^{*}$ & 9.9384 & $7.5561^{*}$ \\
\hline
\end{tabular}

*Indicates lag order selected by the criterion

Source: Author's Computation Using E-view 10.

\subsection{Vector Error Correction Estimates}

The long run vector error correction estimates of private domestic investment (PDI) are presented in table 4 in order to achieve the second, fourth and fifth research objectives. The second research objective is to determine the effect of interest rate on private domestic investment. The regression coefficient of interest rate with respect to private domestic investment is negative and it is statistically significant. This result indicates that interest rate has a significant negative long run relationship with private domestic investment in Nigeria. An increase in interest rate reduces private domestic investment in Nigeria. This result confirms the classical proposition that the demand for loan-able funds (investment) will increase when interest rate declines and decrease when interest rate rises.

The fourth research objective is to determine the effect of public domestic borrowing on private domestic investment. The regression coefficient of public domestic borrowing (PDB) with respect to private domestic investment is negative and it is statistically significant. The public domestic borrowing has a significant crowding-out effect on private domestic investment in Nigeria. This result conforms to the monetarist's view that public domestic borrowing crowds-out private domestic investment. This result does not tally with the finding by Nwaeze (2017) that public domestic borrowing crowds-in private domestic investment in Nigeria.

The fifth research objective is to determine the effect of public external borrowing on private domestic investment. The regression coefficient of public external borrowing (PEB) with respect to private domestic investment is positive and it is statistically significant. This result shows that public external borrowing has a significant crowding-in effect on private domestic investment in Nigeria. This result suggests that private domestic investment will increase in Nigeria if funds are borrowed from external sources to finance the federal government budget deficit. This result is not in line with the finding by Nwaeze (2017) that public external borrowing crowds-out private domestic investment in Nigeria.

Table 4: Long Run Vector Error Correction Estimates of LNPDI

\begin{tabular}{|c|c|c|c|}
\hline Regressor & Coefficient & Standard Error & t-statistic \\
\hline LNPDB (-1) & -1.7739 & 0.0592 & -29.9739 \\
\hline LNPEB (-1) & 0.2007 & 0.0221 & 9.0857 \\
\hline LNDCB (-1) & 0.2173 & 0.0441 & 4.9319 \\
\hline INR (-1) & -0.0372 & 0.0124 & -3.0143 \\
\hline
\end{tabular}

Source: Author's Computation Using E-view 10.

The short run error correction estimates of interest rate (INR) are presented in table 5 in order to achieve the first research objective. The first research objective is to determine the effect of public borrowing on interest rate in Nigeria. The regression coefficient of public domestic borrowing (PDB) with respect to interest rate is positive. A 100 percent increase in public domestic borrowing leads to 800 percent increase in interest rate. Public domestic borrowing drives up interest rate in Nigeria. This result is in tandem with the monetarist's view that if public borrowing increases, the demand curve for loanable funds increases and interest rate rises. The regression coefficient of public external borrowing (PEB) with respect to interest rate is negative. A 100 percent increase in public external borrowing leads to 518 percent decrease in interest rate. Public external borrowing drives down interest rate in Nigeria.

The regression coefficient of domestic credit provided by banks with respect to interest rate is negative and it is statistically significant. Given the demand for loanable funds, an increase in the supply of loanable funds leads to the reduction of interest rate. This result is in line with the classical view about the credit market.

The coefficient of error correction term is negative and statistically significant. The negative sign of the error correction term indicates a backward movement toward long run equilibrium from short run disequilibrium. Table 5 reveals that the deviation of interest rate in the short run from long run equilibrium is corrected by 63.37 percent in one year.

Table 5: Short Run Error Correction Estimates of D(INR)

\begin{tabular}{|c|c|c|c|}
\hline Regressor & Coefficient & Standard Error & t-statistic \\
\hline Intercept & -2.4596 & 1.4639 & -1.6802 \\
\hline D[LNPDI(-3)] & 8.6986 & 4.2892 & 2.0280 \\
\hline D[LNPDB(-1)] & 8.0036 & 4.4357 & 1.8044 \\
\hline D[LNPEB(-3)] & -5.1830 & 1.82412 & -2.8414 \\
\hline D[LNDCB(-3)] & -6.0524 & 1.7873 & -3.3863 \\
\hline D[INR(-1) & -0.9117 & 0.1933 & -4.7157 \\
\hline ECM(-1) & -0.6337 & 0.2790 & -2.2713 \\
\hline
\end{tabular}

R-squared: 0.7868 S. E. equation: 2.6738 F-statistic: 2.9991

Source: Author's Computation Using E-view 10 
The short run vector error correction estimates of private domestic investment (PDI) are presented in table 6 in order to achieve the second, fourth and fifth research objectives. The second research objective is to determine the effect of interest rate on private domestic investment. The regression coefficient of interest rate with respect to private domestic investment is negative. A 100 percent increase in interest rate leads to 1.21 percent decrease in private domestic investment in Nigeria. This result confirms the classical proposition that the demand for loan-able funds (investment) will increase when interest rate declines and decrease when interest rate rises. This result also supports the Keynesian proposition that investment is influenced more by other factors than interest rate.

The fourth research objective is to determine the effect of public domestic borrowing on private domestic investment. The regression coefficient of public domestic borrowing (PDB) with respect to private domestic investment is negative. The public domestic borrowing has a crowding-out effect on private domestic investment in Nigeria. This result conforms to the monetarist's view that public domestic borrowing crowds-out private domestic investment. This result does not tally with the finding by Nwaeze (2017) that public domestic borrowing crowds-in private domestic investment in Nigeria.

The fifth research objective is to determine the effect of public external borrowing on private domestic investment. The regression coefficient of public external borrowing (PEB) with respect to private domestic investment is positive. This result shows that public external borrowing has a crowding-in effect on private domestic investment in Nigeria. This result suggests that private domestic investment will increase in Nigeria if funds are borrowed from external sources to finance the federal budget deficit. This result is not in line with the finding by Nwaeze (2017) that public external borrowing crowds-out private domestic investment in Nigeria.

The coefficient of error correction term is negative but statistically insignificant. The negative sign of the error correction term indicates a backward movement toward long run equilibrium from short run disequilibrium. Table 6 reveals that the deviation of private domestic investment in the short run from long run equilibrium is corrected by 6.95 percent in one year.

Table 6: Short Run Error Correction Estimates of D(LNPDI)

\begin{tabular}{|c|c|c|c|}
\hline Regressor & Coefficient & Standard Error & t-statistic \\
\hline Intercept & 0.1934 & 0.0718 & 2.6939 \\
\hline $\mathrm{D}[$ LNPDI(-2)] & -0.2697 & 0.2462 & -1.0954 \\
\hline $\mathrm{D}[$ LNPDB(-1)] & -0.3092 & 0.2176 & -1.4211 \\
\hline $\mathrm{D}[$ LNPEB(-3)] & 0.0187 & 0.0895 & 0.2091 \\
\hline $\mathrm{D}[\mathrm{LNDCB}(-2)]$ & 0.0686 & 0.1000 & 0.6862 \\
\hline $\mathrm{D}[\mathrm{INR}(-1)]$ & -0.0121 & 0.0095 & -1.2767 \\
\hline ECM(-1) & -0.0695 & 0.1369 & -0.5077 \\
\hline
\end{tabular}

R-squared: 0.8504 S. E. equation: 0.1312 F-statistic: 4.6197

Source: Author's Computation Using E-view 10.
Table 7 presents the short run error correction estimates of domestic credit provided by banks (DCB) in order to achieve the third research objective. The third research objective is to determine the effect of interest rate on domestic credit provided by banks. The regression coefficient of interest rate with respect to domestic credit provided by banks is positive and statistically significant. This result is in line with the classical view that the supply of loan-able funds (saving) is directly related to the interest rate.

The regression coefficient of public external borrowing with respect to domestic credit provided by banks is positive. The public external borrowing crowds-in private domestic investment because it increases the domestic credit provided by banks. Given the demand for loanable funds, an increase in domestic credit provided by banks leads to the reduction of interest rate. The private domestic investment increases as interest rate rises.

The coefficient of error correction term is negative but statistically insignificant. The negative sign of the error correction term indicates a backward movement toward long run equilibrium from short run disequilibrium. Table 7 reveals that the deviation of domestic credit provided by banks in the short run from long run equilibrium is corrected by 49.37 percent in one year.

Table 7: Short Run Error Correction Estimates of D(LNDCB)

\begin{tabular}{|c|c|c|c|}
\hline Regressor & Coefficient & Standard Error & t-statistic \\
\hline Intercept & 0.3091 & 0.2216 & 1.3950 \\
\hline D[LNPDI(-2)] & 0.5441 & 0.7599 & 0.7160 \\
\hline D[LNPDB(-3)] & 0.6466 & 0.5837 & 1.1076 \\
\hline $\mathrm{D}[$ LNPEB(-2)] & 0.934028 & 0.53267 & 1.75347 \\
\hline $\mathrm{D}[\mathrm{LNDCB}(-3)]$ & -0.3416 & 0.2706 & -1.2627 \\
\hline $\mathrm{D}[\mathrm{INR}(-3)]$ & 0.0771 & 0.0336 & 2.2924 \\
\hline ECM(-1) & -0.4937 & 0.4224 & -1.1690 \\
\hline
\end{tabular}

R-squared: 0.5628 S. E. equation: 0.4048 F-statistic: 1.0460

Source: Author's Computation Using E-view 10.

\subsection{Post-Estimation Tests}

The results of the VEC residual serial correlation LM tests are shown in table 8. The Edgeworth expansion corrected likelihood ratio statistic at lags 1, 2, 3, and 4 and at 25 degrees of freedom are $11.6149,30.1549,21.2215$ and 28.1756 and their p-values are $0.9894,0.2185,0.6802$, and 0.2998 respectively. The Rao F-statistic at lags 1, 2, 3 and 4 and at 25 and 16.4 degrees of freedom are $0.3385,1.2772,0.7473$ and 1.1447 and their p-values are $0.9927,0.3083,0.7507$ and 0.3959 respectively. The null hypothesis of no serial correlation at lags 1 to 4 is accepted because of high p-values. 
Table 8: VEC Residual Serial Correlation LM Tests

\begin{tabular}{|c|c|c|c|c|c|c|}
\hline Lag & $\begin{array}{c}\text { LRE* } \\
\text { stat }\end{array}$ & Df & Prob. & Rao F-stat & df & Prob. \\
\hline 1 & 11.6149 & 25 & 0.9894 & 0.3385 & $(25,16.4)$ & 0.9927 \\
\hline 2 & 30.1549 & 25 & 0.2185 & 1.2772 & $(25,16.4)$ & 0.3083 \\
\hline 3 & 21.2215 & 25 & 0.6802 & 0.7473 & $(25,16.4)$ & 0.7507 \\
\hline 4 & 28.1756 & 25 & 0.2998 & 1.1447 & $(25,16.4)$ & 0.3959 \\
\hline
\end{tabular}

*Edgeworth expansion corrected likelihood ratio statistic

Source: Author's Computation Using E-view 10.

The results of the VEC residual normality tests are shown in table 9. Instead of going for any rule of thumb for the acceptable ranges of skewness and kurtosis for normal distribution of data, the Jarque-Bera test is used. This is because Jarque-Bera test is based on skewness and Kurtosis and so the acceptance of the null hypothesis in this test means that skewness and kurtosis are within the acceptable ranges for normality, and the rejection of the null hypothesis in this test means that skewness and kurtosis are not in acceptable ranges for normality of the data. The Jarque-Bera (JB) statistic is 8.9810 and the computed p-value is 53.39 percent. The computed p-value of JB statistic is very high which indicates that the value of the JB statistic is close to zero. Therefore, the null hypothesis that the residuals are multivariate normal is accepted.

Table 9: VEC Residual Normality Tests

\begin{tabular}{|c|c|c|c|}
\hline Component & Jarque-Bera & Df & Prob. \\
\hline 1 & 0.4450 & 2 & 0.8005 \\
\hline 2 & 1.9371 & 2 & 0.3796 \\
\hline 3 & 0.2455 & 2 & 0.8845 \\
\hline 4 & 0.6922 & 2 & 0.7074 \\
\hline 5 & 5.6612 & 2 & 0.0590 \\
\hline Joint & 8.9810 & 10 & 0.5339 \\
\hline
\end{tabular}

Source: Author's Computation Using E-view 10.

The Inverse Roots of Autoregressive (AR) Characteristic Polynomial is presented in figure 1 in order to verify whether the VEC model is stable. The VEC model is stable if all roots of AR characteristic polynomial in absolute value are less than one and lie inside the unit circle. In this study, one of the roots lies on the unit circle which indicates that the VEC model is unstable. That is the impact of the shock in some variables might not decrease with time.

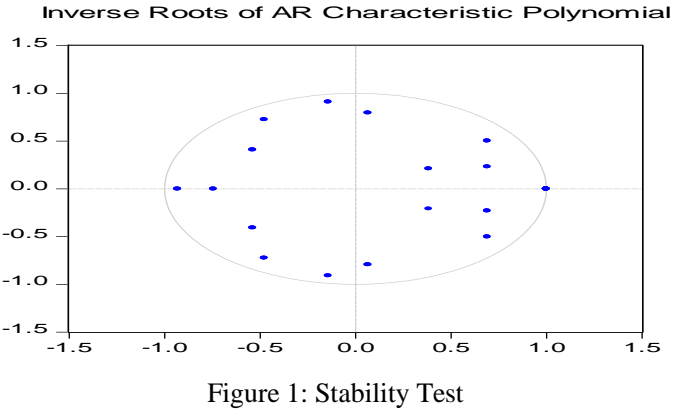

Source: Author's E-view Result

\subsection{Summary of Research Findings}

From an investigation of the crowding-out and crowding-in effects of public borrowing on private domestic investment in Nigeria, the followings are the summary of the research findings.

a) Public domestic borrowing drives-up interest rate and public external borrowing drives-down interest rate.

b) Interest rate has a significant negative effect on private domestic investment.

c) Interest rate has a significant positive effect on domestic credit provided by banks.

d) Public domestic borrowing crowds-out private domestic investment

e) Public external borrowing crowds-in private domestic investment in Nigeria.

\subsection{Policy Implications of Research Findings}

a) Interest rate will increase if government borrows money from domestic sources and interest rate will reduce if government borrows money from external sources to finance the federal budget deficits.

b) Private domestic investment will increase if interest rate falls.

c) Domestic credit provided by banks will increase if interest rate rises.

d) Private domestic investment will decrease if government borrows money from domestic sources to finance the federal budget deficits.

e) Private domestic investment will increase if government borrows money from external sources to finance the federal budget deficits.

\section{CONCLUSIONS}

The following conclusions based on research findings are drawn. The monetarist view that public domestic borrowing increases interest rate is applicable to Nigeria. The Keynesian view that public domestic borrowing has no effect on interest rate is not applicable to Nigeria. In line with the classical view about the credit market, private domestic investment is a decreasing function of interest rate and domestic credit provided by banks is an increasing function of interest rate in Nigeria. The monetarist view that public domestic borrowing crowds-out private domestic investment is applicable to Nigeria. The Keynesian view that public domestic borrowing does not crowd-out private domestic investment is not applicable to Nigeria. In line with the dual gap theory, public external borrowing crowds-in private domestic investment in Nigeria.

\section{REFERENCES}

[1] Afonso, A.; and Sousa, R. M. (2011). "The Macroeconomic Effects of Fiscal Policy in Portugal: A Bayesian SVAR Analysis" in Portuguese Economic Journal, 10(1), pp. 61-82. 
[2] Amacher, R. C. and Ulbrich, H. H. (1986). Principles of Macroeconomics. Third Edition, Cincinnati, Ohio: South-Western Publishing Co.

[3] Atukeren, E. (2005). "Interactions between Public and Private Investment: Evidence from Developing Countries" in Kyklos, 58(3), pp. 307-330.

[4] Bahal, G.; Raissi, M.; and Tulin, V. (2015). "Crowding-Out or Crowding-In? Public and Private Investment in India" in IMF Working Paper, WP/15/264, pp. 1-23.

[5] Bahovec, V. and Erjavec, N. (2009). Uvod u ekonometrijsku analizu. Zagreb: Element.

[6] Dickey, D. A. and Fuller, W. A. (1979). "Distribution of the Estimators for Autoregressive Time Series with a Unit Root" in Journal of the American Statistical Association, 74, pp. 427-431.

[7] Engle, R. F. and Granger, C. W. J. (1987). "Cointegration and Error Correction: Representation, Estimation and Testing" in Econometrica, 55, pp. 251-276.

[8] Enders, W. (1995). Applied Econometrics Time Series. New York: John Wiley and Sons.

[9] Enders, W. (2015). Applied Econometric Time Series. London: John Wiley and Sons.

[10] Feasel, E.; Kim, Y. and Smith S. C. (2001). "A VAR Approach to Growth Empirics: Korea" in Review of Development Economics, 53, pp. 421-432.

[11] Furceri, D. and Sousa R. M. (2011). "The Impact of Government Spending on the Private Sector: Crowding-Out versus CrowdingIn Effects" in Kyklos, 64(4), pp. 516-533.

[12] Gjini, A. and Kukeli, A. (2012). "Crowding-Out Effect of Public Investment on Private Investment: An Empirical Investigation" in Journal of Business and Economics Research, 10(5), pp. 269-276.

[13] Ifeakachukwu, N. P.; Omodadepo, A. O. and Oluseun, A. A. (2013). "An Analysis of the Relationship between Public Spending Components and Private investments in Nigeria" in Journal of Finance and Economics, 1(2), pp. 1-14.

[14] Johansen, S. (1988). "Statistical Analysis of Cointegrating Vectors" in Journal of Economic Dynamics and Control, 12, pp. 231-54.

[15] Karagöl, E. (2004). "A Disaggregated Analysis of Government Expenditures and Private Investment in Turkey" in Journal of Economic Cooperation, 25(2), pp. 131-144.

[16] Kollamparambil, U. and Nicolaou, M. (2011). "Nature and Association of Public and Private Investment: Public Policy Implications for South Africa" in Journal of Economics and International Finance, 3(2), pp. 98-108.

[17] Kuştepeli, Y. (2005). "Effectiveness of Fiscal Spending: Crowding-Out and/or Crowding-In?" in Yönetimveekonomi, 12(1), pp. 185-192.

[18] Mahmoudzadeh, M.; Sadeghi, S. and Sadeghi, S. (2013). "Fiscal Spending and Crowding-Out Effect: A Comparison between Developed and Developing Countries" in Institutions and Economies, 5(1), pp. 31-40.

[19] Mitra, P. (2006). "Has Government Investment Crowded-Out Private Investment in India?" in American Economic Review, 96(2), pp. 337-341.

[20] Mittnik, S. and Neumann, T. (2001). "Dynamic Effects of Public Investment: Vector Autoregressive Evidence from Six Industrialized Countries" in Empirical Economics, 26(2), pp. 429446.

[21] Nwaeze, N. C. (2017). "Public Borrowing and Private Investment in Nigeria: Any Crowding-Out Effect?" in JORIND, 15(2), pp. 2434.

[22] Omitogun, O. (2018). "Investigating the Crowding-Out Effect of Government Expenditure on Private Investment" in Journal of Competitiveness, 10(4), pp. 136-150.

[23] Omojolaibi, J. A.; Okenesi, T. P. and Mesagan, E. P. (2016). "Fiscal Policy and Private Investment in Selected West African Countries" in CBN Journal of Applied Statistics, 7(1b), pp. 277 309.

[24] Palić, I., Dumičić, K. and Barbić, D. (2016). The Estimation of Money Demand Elasticity: Case of Croatia. International Journal of Research in Business, Vol. 4, No. 9, pp. 89-98.
[25] Palić, I.; Žmuk, B. and Grofelnik, B. (2017). "The long-Run Impact of Personal Income Taxation on Economic Development: Evidence from Croatia" in Croatian Review of Economic, Business and Social Statistics, 3(1), pp. 35-44.

[26] Ricardo, D. (1820). "Essay on the Funding System". In McCulloch, J. R. (ed.), 1888: The Works of David Ricardo. London: John Murray.

[27] Voss, G. M. (2002). "Public and Private Investment in the United States and Canada" in Economic Modeling, 19(4), pp. 641-664.

[28] Xu, X. and Yan, Y. (2014). "Does Government Investment Crowd-Out Private Investment in China?" in Journal of Economic Policy Reform, 17(1), pp. 1-12. 